\title{
Review of Oil and Gas Development Life Cycle Project Management (LCPM)
}

\author{
Yongqin Yan ${ }^{*}$, Haohan Liu ${ }^{2}$ \\ ${ }^{1}$ Southwest Petroleum University, Sichuan, China \\ ${ }^{2}$ Sichuan College of Architectural Technology, Deyang, China \\ Email: "yanyongqin77@126.com
}

Received 10 February 2016; accepted 11 March 2016; published 14 March 2016

Copyright (C) 2016 by authors and Scientific Research Publishing Inc.

This work is licensed under the Creative Commons Attribution International License (CC BY). http://creativecommons.org/licenses/by/4.0/

\section{cc) (i) Open Access}

\section{Abstract}

The effective implementation of the project management plays a core roll in avoiding bad project use effect and waste of funds, caused by asset management planning and design errors or equipment selection errors; meanwhile, it can effectively improve the operational efficiency of enterprise assets, lower operating costs and save resources. In June 1974, A. Gordon published a paper "3L Economics Concept" as the starting point, on the "Building and Quantity Surveying", which is organized by the Royal Institution of Chartered Surveyors. In this paper, a review of domestic and foreign research, from 1974 to 2015 , on the total life cycle management progress will be given, and then a comment on it will be established. After detailed investigation and analysis of related materials, we can draw a conclusion: the study of the oil and gas development project lifecycle management is just beginning now. Hence, building the whole life cycle planning index system in line with the characteristics of oil and gas development project is very necessary.

\section{Keywords}

Project, Life Cycle, Management, Review

\section{Introduction}

Whole LCPM of oil and gas development is essential to oil and gas development project as the management object. The ultimate goal of it is to realize the overall optimal economic benefit; the basis of it is the modern project management theory and total life cycle management thoughts, and according to a certain organization form, it makes the whole process, the whole functional areas, and the whole levels integration management of oil and gas development project. The whole LCPM is the system engineering to realize the sustainable development of oil and gas development project.

\footnotetext{
${ }^{*}$ Corresponding author.
} 


\section{Foreign Research Status of LCPM}

The thoughts of Lifecycle management in applied research and practice of project management can be traced back to one article [1] "3L Economics Concept", which is a published on a Quarterly published journal "Building and Quantity Surveying” organized by the Royal Institution of Chartered Surveyors, in June 1974, and a book [2] "full life-cycle cost analysis life-architects Guide” published by the American institute of architects in 1977. Subsequent development of LCPM mainly focused on three different stages: introduction, applications and integration. The research and application scope involves in studying the life cycle and phase division, professional management function, system integration.

The Royal Institution of Chartered Surveyors defines the earliest LCPM: LCPM includes three stages; they are the project construction process, the operational use process and the final liquidation process. And wherein each stage can specifically divided into more detailed phase, these stages constitute of the total project life cycle.

O. Orshan (1980) published an article "Life Cycle Cost: Compare architectural design tools". From the perspective of architectural design for comparison, this paper proposed a concept: in architectural design, the construction, operation and maintenance costs should be fully considered [3].

R.C. Petts and J. Brooks (1986) proposed a full life-cycle cost model and its possible applications. The article not only gives a full life-cycle cost management model, and it also explores the full range of application of lifecycle project cost management [4].

J. W. Bull (1993) et al. published a paper "Building Life Cycle Cost Management”, which gave the basic concepts, basic theory and main methods of the total life cycle cost management [5].

LG Medley (1996) published an article "Departure from the Life Cycle: Management before the Occurrence of Cost". From the perspective of the project management cost in advance, the article discussed how to use the life cycle cost methods to compare and select the project plan [6]. These scholarly articles discussed the ideas and methods of life cycle cost in-depth from different angles.

Jaafari, a professor at the University of Sydney, Australia (1997), first proposed the thought of LCPM. Through study of the parallel construction, intelligent project management information systems and integration of LCPM process, Jaafari proposed general project management model, Shifting from the traditional cost, time and quality targets for the whole life cycle of a target [7] [8].

Kerzner H. (2001) proposed: Due to the complexity and diversity of the project, division of the total project life cycle stages are different in different industries or in different companies of the same industry. In general, LCPM can be divided into five stages, including concept, planning, testing, implementation and the end [9].

John. W. Bull (2003) published a book “Cost Estimate of Life-Cycle Construction Projects”. The book analyzes the relationship between the cost of construction, operation and maintenance with the life-cycle costs, meanwhile a diagram is also been given [10].

Based on the research of Dhillon B, Tsai WH (2014) focused on the green building evaluation method of the entire life cycle, green building project cost evaluation activity based on cost concept and full life-cycle concept model based on green building. This paper proposed implementation of integrated life cycle assessment methods and construction cost management through establishing comprehensive decision model of green building project [11].

In Jordy Batselier's research (2015), a real-life project database is created, outranking the existing empirical databases from project management literature in both size and diversity [12].

\section{LCPM Research State in China}

Dr. Qi Anbang (2000) published a book “Total Cost Management of Project”, this book gives a brief introduction on the life cycle cost management theory and methods, this is the earliest writings in life cycle cost management [13].

Qi Anbang (2000) and Qi Anbang (2001) wrote another two books “Modern Project Management” and "Project Risk Management", both of them are life cycle related books, and give detailed introduction in project management [14] [15].

In 1999, Ding Shizhao, professor of Tongji University, |published a paper "Discussion on Establishment of Project Life Management System-a new general conception of management systems integrated with DM, PM and FM", this article starts from the research of project management rather than the perspective of project cost. In this article, establishment of LCPM information system-theory and method is discussed, and the investment 
control problems in life cycle decision management stage are also mentioned [16].

He Qinghua (2001) analyzed the relationship between construction cost and operating and maintenance costs, in his doctoral thesis "Study of integrated management model construction on life cycle project". He suggests that more attention to the decision-making stage and early design stage should be paid to ensure the optimization of total life cycle cost target [17].

Based on the early study of life cycle and project management at home and abroad, Zeng Cheng et al. (2005) introduced the conception of total life cycle and formed a Web-based project management system, concerning the problem that the traditional project management centers on the planning and execution and ignore the tender and customer feedback [18].

Liu Yuqi et al. (2008) proposed that total life cycle project is not a simple life cycle phases, but rather the decomposition and the effective integration of the whole life cycle project. His research shows that full attention should be paid to deliverables in each stage, and each stage is in the service of LCPM value [19].

Liyan Fei (2010) divided the LCPM into five stages: decision-making, design, bidding, project implementation and the trial after project completion [20].

Lei Zhongying (2010) studied the construction principles of later evaluation index system and comprehensive evaluation system of oil and gas development project. His research shows that effective evaluation work of oil and gas development project is especially important to scientific and comprehensive developing investment [21].

Analyzing the characteristics of oil and gas field development projects and specific management practices, Qi Yanping (2011) proposed comprehensive evaluation method of oil and gas development project management using the fuzzy comprehensive evaluation principle. From the prospective of oil and gas development project life cycle and knowledge system, he established the evaluation index system of oil and gas development project management [22].

Started from the definition of total life cycle, Liu Bin (2012) studied the economical evaluation method and evaluation index system of life cycle project. According to the stage differences of life cycle project, the life cycle is divided into three stages: Feasibility study phase, project operation phase and the end of the project. He proposed the evaluation indexes in each stage, this new thought is different to the traditional evaluation model, and it establishes multi-level and multi-angle comprehensive economical evaluation method. This new method embodied the comprehensive economical benefit of project construction, and laid a solid evaluation basis to improve investment efficiency for old oilfields [23].

Based on the studies of Liu Bin and Qi Yanping, Luo Lingrui (2013) showed: Petro China Southwest Oil and Gas Field Company proceeded three times 5-year follow-up assessment for Jiu Long Shan gas field total life cycle investment returns. Through definition of project life cycle, his research constructed follow-up assessment system of oil and gas field development construction project: follow-up assessment of oil and gas field development project is benefit for the entire process management of oil and gas development. It is good for finding out the problems in developing and providing decision-making reference for the investment to achieve maximum investment benefit [24].

According to Dr Qi Anbang's research on project management and project risk management, Xue Qi and Wu Qing (2014) conducted in-depth research on the establishment of risk management models of life cycle project and their applications, including process model, hierarchical model, relational model, fault model and risk control processes model [25]. They used the total life cycle model to power construction projects, which gets theoretical and practical significance in carrying out total life cycle management of other fields [26].

Companies of Exxon and Shell firstly proposed "life-cycle" concept in the development of oil and gas fields. In the end of $20^{\text {th }}$ century, Scholars in China put forward the concept of "life-cycle oil”, it actually flourished from the 2005-year-old oil field "secondary development” Practice. In the beginning of 2014, China National petroleum Corporation for the first time formally proposed the implementation of oil and gas pipeline construction project life cycle management concept and gains some breakthroughs [27].

\section{Comment on LCPM}

Through the investigation and analysis of LCPM and oil and gas development projects at home and abroad, three conclusions can be achieved:

1) LCPM study for scholars abroad is earlier than that of China, especially on the construction industry. There are more comprehensive introductions of the LCPM process and stage division; meanwhile, differences exist in 
the stage division of different industries. These studies lay a certain foundation for follow-up studies. However, studies on LCPM of oil and gas development project are not enough in-depth.

2) There are many problems in domestic research on LCPM in China:

The earliest start of domestic research on the total life cycle is in construction industry, and the development in other fields is relatively slow. Afterwards, scholars introduce the total life cycle to project management and achieve some breakthrough. In recent years, some scholars introduce the concept of life cycle to the petroleum industry, but there is lack of a complete theoretical system, for the reason that it covers a wide range and involves complex content.

3) Considering the status of life cycle and project management home and abroad, life cycle in oil and gas development project needs further researches. Hence, it is necessary to construct total life cycle planning index system considering the characteristics of oil and gas development project.

\section{Acknowledgements}

This paper is funded by the Sichuan Provincial Education Department general project funding (NO: 15ZB0447).

\section{References}

[1] Gordon, A. (1974) The Economic of the 3L'5 Concept. Charted Survey or Building and Quantity Surveying.

[2] America Institute of Architects (1997) Life Cycle Cost Analysis: A Guide for Architects. AIA, USA.

[3] Orshan, O. (1980) Life Cycle Cost: A Tool for Comparing Building Alternative. Proceeding Symposium on Quality and Cost in Building, 1, 63.

[4] Bull, J.W. (1993) The Way Ahead for Life Cycle Costing in the Construction Industry. In: Bull, J.W., Ed., Life Cycle Costing for Construction, Blackie Academic \& Professional, Glasgow.

[5] Wyley, W.J., Petts, R.C. and Brooks, J. (1986) Evaluation of the World Bank's Highway Design and Maintenance Standards Model on United Kingdom Highways.

[6] Jaafari, A. (2001) Management of Risks, Uncertainties and Opportunities on Projects: Time for a Fundamental Shift. International Journal of Project Management, 19, 89-101. http://dx.doi.org/10.1016/S0263-7863(99)00047-2

[7] Kerzner, H. (2001) Project Management; Systems Approach to Planning, Scheduling and Controlling. John Wesley and Sons, New York.

[8] Bull, J.W. (2003) Life Cycle Costing for Construction. Routledge, Abingdon-on-Thames.

[9] Medley Sr., L.G. (1996) The Life-Cycle Perspective: Managing Cost before It Occurs. Cost Engineering-Morgantown, 38, 35-39.

[10] Jaafari, A. (1997) Concurrent Construction and Life Cycle Project Management. Journal of Construction Engineering and Management, 123, 427-436. http://dx.doi.org/10.1061/(ASCE)0733-9364(1997)123:4(427)

[11] Tsai, W.H., Yang, C.H., Chang, J.C., et al. (2014) An Activity-Based Costing Decision Model for Life Cycle Assessment in Green Building Projects. European Journal of Operational Research, 238, 607-619. http://dx.doi.org/10.1016/j.ejor.2014.03.024

[12] Batselier, J. and Vanhoucke, M. (2015) Construction and Evaluation Framework for a Real-Life Project Database. International Journal of Project Management, 33, 697-710. http://dx.doi.org/10.1016/j.ijproman.2014.09.004

[13] Qi, A.B. (2000) Project Total Cost Management. Nankai University Press, Tianjin. (In Chinese)

[14] Qi, A.B. (2001) Modern Project Management. Foreign Economic and Trade University Publishing House, Beijing. (In Chinese)

[15] Qi, A.B. (2010) Project Risk Management. Nankai University Press, Tianjin. (In Chinese)

[16] Ding, S.Z. (1999) Discussion on Establishment of Project Life Management System—A New General Conception of Management Systems Integrated with DM, PM and FM. Construction Supervision Institute of Tongji University, Shanghai. (In Chinese)

[17] He, Q.H. and Chen, F.B. (2001) Study of Integrated Management Model Construction on Life Cycle Project. Journal of Chongqing Construction University, 23. (In Chinese)

[18] Zeng, C., Wang, A.M. and Xiao, T.Y. (2005) Total Life Cycle Project Management System Analysis and Design. Computer Engineering and Design, 26, 853-856. (In Chinese)

[19] Liu, Y.Q., Qi, A.B. and Yang, Y.W. (2008) Research on Total Life Cycle Project Management Method of Government Investment Project Agent Enterprise. Proceedings of the 10th Annual Meeting of China Association for Science and 
Technology, 4. (In Chinese)

[20] Li, Y.F. and Qi, A.B. (2010) Engineering Project Risk Management System Problem and Countermeasure Analysis. Project Management Techniques, 2, 79-82. (In Chinese)

[21] Lei, Z.Y. and Hu, W.S. (2010) Construction of Later Comprehensive Evaluation Index System of Oil and Gas Field Development Project. Journal of Oil and Gas, 10, 391-393. (In Chinese)

[22] Qi, Y.P. (2011) Oil and Gas Field Development Project Management Evaluation Research Based on the Fuzzy Comprehensive Evaluation. Project Management Techniques, 5, 96-100. (In Chinese)

[23] Liu, B. (2012) Total Life Cycle of Project Economic Evaluation Method. International Petroleum Economy, 7, 65-67. (In Chinese)

[24] Luo, L.R., Chen, C.-Y. and Wang, J. (2013) Follow-Up Assessment of Oil and Gas Life Cycle Project Construction. Natural Gas Technology and the Economy, 7, 51-53. (In Chinese)

[25] Ding, H. (2014) Project Management System Construction Based on Total Life Cycle. Electric Power, 12. (In Chinese)

[26] Xue, J. and Wu, Q. (2014) The Establishment of the Total Life Cycle of Project Risk Management Model and Its Application. Journal of Northwestern Polytechnical University: Social Science Edition, 34, 44-49. (In Chinese)

[27] Chi, H.J. (2014) Total Life Cycle Project Management of China’s Oil and Gas Pipeline. International Petroleum Economy, 22, 86-91. (In Chinese) 